PIOTR OSTAŃSKI, POZNAŃ

\title{
PROPOZYCJA NOWEJ INTERPRETACJI AP 3,14
}

Jednym z tytułów Chrystusa w Liście do Kościoła w Laodycei w Księdze Apokalipsy jest „Amen”: „Aniołowi Kościoła w Laodycei napisz: To mówi AMEN, Świadek wierny i prawdomówny, Początek stworzenia Bożego" (Ap 3,14).

Tematem niniejszego artykułu będzie tradycyjna wykładnia tego imienia Chrystusa, a także propozycja jeszcze innej interpretacji.

\section{Imiona Chrystusa w listach Apokalipsy}

Jedną z cech charakterystycznych listów do siedmiu Kościołów w Apokalipsie jest ich kompozycja formalna - wszystkie listy mają identyczny schemat. Jego pierwszym elementem, pełniącym rolę wstępu, jest polecenie Chrystusa skierowane do Jana, aby przygotował pismo do wskazanego adresata („Aniołowi Kościoła w... napisz").

Zaraz potem następuje formuła, którą Chrystus potwierdza, że treść listów będzie pochodzić od Niego („To mówi...”). Formuła ta ma swój pierwowzór w wyrażeniu „To mówi Jahwe” (albo „Wyrocznia Jahwe") w Starym Testamencie, którym prorocy wprowadzali słowa Boga (np. Jr 2,2; Za 7,9). W Apokalipsie imię „Jahwe” zostało zamienione na „Chrystus” („To mówi [Chrystus]”), a dokładniej - na jedno z określeń Chrystusa, które pojawiły się już wcześniej we wizji wstępnej (Ap 1,9-20), bądź też pojawią się dopiero (bezpośrednio lub domyślnie) w dalszych częściach księgi. ${ }^{1}$

Dla przykładu: określeniem Chrystusa w Liście do Kościoła w Smyrnie jest: „Pierwszy i Ostatni, który był martwy, a ożył” (Ap

1 Por. A. Ja n k ow s k i, Apokalipsa świętego Jana. Wstęp - przekład z oryginatu-komentarz, Poznań 1959, s. 297. 
2,8), do Kościoła w Sardach - „Ten, co ma Siedem Duchów Boga i siedem gwiazd" (Ap 3,1), a do Kościoła w Laodycei, będącym przedmiotem niniejszego opracowania - „Amen, Świadek wierny i prawdomówny, Początek Bożego stworzenia” (Ap 3,14).

Jaka prawda o Chrystusie kryje się w tytulaturze „Amen” w Ap 3,14 ?

\section{„Amen” w Starym Testamencie}

Hebrajskie słowo 'āmēn było pierwotnie przymiotnikiem od rdzenia 'mn, który wyraża ideę „,bycia mocnym”, „pewnym”, „niezawodnym”, a dalej - ,godnym wiary” i ,prawdomównym”. W tym podstawowym znaczeniu 'āmēn pojawia się w kontekście mocnych rąk rodzica, które podtrzymują słabe dziecko ( $2 \mathrm{Krl} \mathrm{10,1.5;} \mathrm{Est} \mathrm{2,7)}$ albo silnych filarów podtrzymujących bramę wejściową $(2 \mathrm{Krl} 18,16)$. Najczęściej jednak słowo 'āmēn jest używane w Piśmie Świętym jako przysłówek albo partykuła.

Autorzy Starego Testamentu używają terminu 'āmēn w następujących sytuacjach:

- jako odpowiedzi wyrażającej zgodę na rozwój wypadków, które będą zależeć od Boga (np. Jr 11,5), a także jako odpowiedzi potwierdzającej rozkaz $(1 \mathrm{Krl} 1,36)$, życzenie $(\mathrm{Tb} 8,8)$ albo przekleństwo (np. Lb 5,22; Pwt 27,15nn.; Jr 11,5; Ne 5,13). 'Āmēn w takich przypadkach można by tłumaczyć jako ,niech się tak stanie” albo „tak jest”;

- jako formuły liturgicznej potwierdzającej chwałę należną Bogu, zwykle pojawiającej się na końcu doksologii albo modlitwy błagalnej (1Krn 16,36; Ne 8,6; Ps 41,13; 72,19; 89,52; 106,48). 'Āmēn znaczy wtedy: „doprawdy”, „rzeczywiście”, „faktycznie", ,potwierdzam”.

W każdym z powyższych przypadków partykuła ’āmēn służy potwierdzeniu czegoś, co jest ważne i nie podlega dyskusji.

W judaizmie Izraelici potwierdzali słowem 'āmēn (na wzór 'āmēn w doksologiach biblijnych) wspólnie zanoszone do Boga modlitwy 
w liturgii synagogalnej i odpowiadali trzykrotnie 'ämēn na Aaronowe błogosławieństwo (Lb 6,24-26). Z czasem zaczęto używać 'āmēn także poza liturgią, np. na potwierdzenie dowolnej modlitwy czy składanego ślubu, a nawet - w celu przytaknięcia temu, co ktoś inny mówił.

Tłumacze Septuaginty oddawali często słowo 'āmēn czasownikową formą genoito („oby się tak stało"). Taki przekład osłabił jednak pierwotny sens terminu hebrajskiego, bo jakkolwiek słowo genoito nadal odnosiło się do czegoś ważnego, to już nie tyle je potwierdzało, ile raczej wyrażało życzenie, aby się ono spełniło (1Krn 16,36; Ne $5,13 ; 8,6 ; \mathrm{Tb} 8,8 ; 14,15) .^{2}$

\section{„Amen” w Nowym Testamencie}

Autorzy Nowego Testamentu zachowali hebrajskie słowo 'āmēn $\mathrm{w}$ oryginalnej, niezmienionej formie jako amēn. Jest ono używane w trzech przypadkach: ${ }^{3}$

- pod wpływem liturgii synagogalnej - jako zbiorowa odpowiedź wiernych na inwokacje osoby przewodniczącej nabożeństwu (1Kor 14,16) albo w liturgii niebiańskiej (Ap 5,14). Amēn wyraża tu potwierdzenie i stanowi odpowiedź na słowa uwielbienia;

- jako zakończenie modlitw albo doksologii (np. w Rz 1,25; Ga 1,5; Ef 3,21; Flp 4,20; 1Tm 1,17; 2Tm 4,18; Hbr 13,21; 1P 4,11; Jd 25). ${ }^{4}$ Amēn jest potwierdzeniem przez wiernych usłyszanych słów i przyłączeniem się do nich. W podobnym znaczeniu amēn pojawia się też na końcu proroctw (np. w Ap 1,7) albo listu lub księgi (np. w Rz 15,33; Ga 6,18; Ap 22,20). W Ap 1,7 amēn zostało dodatkowo wzmocnione przez stojącą obok niego partykułę nai (,tak”), a w Ap 22,20 amēn jest odpowiedzią Kościoła na nai Boga, czyli na Jego obietnice (por. 2Kor 1,20);

2 Por. H. S c hli e r, Amen, w: G. J. B o t t e rw e c k, H. R ing g r e n (red.), Theological Dictionary of the New Testament, t. 1, Grand Rapids 1981, s. 335-336.

3 Por. tamie, s. 336-338.

4 Zdarza się, że amēn nie kończy, ale rozpoczyna doksologię, np. w Ap 7,12. 
- jako wstępna formuła uroczystych zapewnień i pouczeń Chrystusa (np. w Mt 5,18; 18,3; Mk 9,1), tłumaczona zwykle jako ,zaprawdę”, ,,jest godne wiary” albo ,prawdziwie”. ${ }^{5}$ Jezus zakazywał stosowania przysięgi (Mt 5,34); zamiast tego poręczał słowem amēn prawdę i wagę wygłaszanych przez siebie nauk. Amēn jest więc pewnego rodzaju transpozycją starotestamentowego zwrotu „To mówi Jahwe". Chrystus jest nie tylko Wysłannikiem Boga i jedynym Nauczycielem prawdy; formuła amēn potwierdza, że Jego słowa są samą prawdą. ${ }^{6}$

Do dziś słowem ,amen” kończy się chrześcijańskie modlitwy, hymny, psalmy, błogosławieństwa, formy sakramentalne i kazania.

Podsumowując, termin 'àmēn/amēn jest w Biblii wyrazem: zgody i przytaknięcia; aprobaty dla cudzych słów i uznania ich za swoje własne oraz solidaryzowania się z nimi; zapewnienia o prawdziwości własnej wypowiedzi.

\section{„Amen" w Ap 3,14}

Jeszcze innego sensu nabiera termin amēn w Liście do Kościoła w Laodycei: „Aniołowi Kościoła w Laodycei napisz: To mówi Amen [ho amēn], Świadek wierny i prawdomówny, Początek stworzenia Bożego" (Ap 3,14).

W pierwszym zdaniu Listu do Kościoła w Laodycei występują trzy ważne i powiązane ze sobą tytuły chrystyczne: Amen; „Świadek wierny i prawdomówny”; „Początek stworzenia Bożego”.

Przedmiotem naszego studium będzie przede wszystkim pierwszy z nich, ho amēn.

Niezwykły w tym określeniu Chrystusa jest fakt użycia partykuły (czy też przysłówka) amēn $\mathrm{w}$ formie rzeczownikowej z rodzajnikiem

5 U Mateusza 30 razy, u Marka 13 razy, u Łukasza 6 razy i 25 razy w formie zdublowanej (amēn amēn) u Jana. Podwojenie nie ma analogii rabinistycznych.

6 Por. C. Th o m a s, Amen, w: X. L e on - D u fou r (red.), Stownik teologii biblijnej, Poznań 1973, s. 47. 
męskim ho, jedyny taki przypadek w Nowym Testamencie. ${ }^{7}$ Jest wielce prawdopodobne, że inspiracją dla takiej tytulatury Chrystusa był hebrajski tekst Iz 65,16, w którym 'Āmēn, jako imię Boga Izraela, występuje dwukrotnie:

„Kto w kraju zechce cię pobłogosławić, wypowie swe błogosławieństwo przez Boga prawdy" (yitbārēk bē'lōhê 'āmēn).

„Kto w kraju będzie przysięgat, przysięgać będzie na Boga wiernego" (yiššăăba' bè'lōhê 'āmēn).

Użyty tu zwrot: yitbārēk bē'lōhê 'āmēn znaczy dosłownie ,[ktoś] będzie błogosławił przez Boga Amen”, zaś wyrażenie: yiššăa ' bè lōhê 'àmēn - oznacza ,[ktoś] będzie przysięgał przez Boga Amen".

Tytuł „Bóg Amen” nie występuje w Biblii nigdzie poza Iz 65,16. Hagiograf powiązał go $\mathrm{w}$ tym fragmencie $\mathrm{z}$ dwoma czynnościami człowieka: błogosławieniem oraz składaniem przysięgi. Zarówno pierwsza, jak i druga czynność, by były ważne, muszą być potwierdzone przez Boga. Dlatego wydaje się zrozumiałe i uzasadnione, że Bóg został określony jako 'Āmēn, czyli „potwierdzam”, „aprobuję”, „zgadzam się”. Jednocześnie zaś Jahwe, który potwierdza zarówno błogosławieństwo, jak i przysięgę, sam nie potrzebuje

7 W 1Kor 14,16 i 2Kor 1,20 amēn poprzedza rodzajnik nijaki „to”.

8 K. E 11 i g e r, W. R u d o l p h (red.), Biblia Hebraica Stuttgartensia, Stutgart 1990, sugeruje, że słowo 'āmēn powinno być wokalizowane albo jako 'ēmûn (,wierność”), albo też jako 'ōmen (,wierność”), ponieważ w Septuagincie oba wyrażenia są oddane jako ton theon ton alētinon („Bóg prawdziwy”). Natomiast w Targumie do Izajasza oba zwroty są oddane jako „żyjący Bóg”.

Zwolennicy wersji bē'lōhê 'āmēn u Izajasza powołują się na przekłady Akwili, Symmachusa i Wulgaty. Co się tyczy Akwili, to wydaje się, że używany przez niego hebrajski tekst Izajasza musiał mieć w Iz 65,16 wersję 'āmēn, a nie 'ēmûn/'ōmen, ponieważ tłumacz oddał je greckim słowem pepistōmeōs (słowem pepistōmeōs tłumaczył też termin 'āmēn w Lb 5,22; Pwt 27,15; Ps 41,23; 72,19; 89,53 i Jr 11,5). Również hebrajski tekst, którym posłużył się Symmachus, musiał mieć wersję 'āmēn, ponieważ przetłumaczył on wyrażenie bè'lōhê 'āmēn jako ton theon amēn. Także Hieronim musiał mieć tekst z wersją 'āmēn, ponieważ dokonał przekładu i transliteracji jako in Deo amen; por. D. A n n e, Revelation 1-5:14, Word Biblical Commentary 52A, Dallas 2002, s. 255. 
niczyjego potwierdzenia, ponieważ jest Świadkiem sam dla siebie (Hbr 6,13-17). ${ }^{9}$

Teologię imienia Bożego z Iz 65,16 można przenieść na Ap 3,14, ponieważ Syn Boży został określony w Apokalipsie tak samo jak Jahwe u Izajasza. Amēn jako tytuł Chrystusa w Liście do Kościoła w Laodycei jest personifikacją tego wszystkiego, co jest treścią tego hebrajskiego (i greckiego) słowa: jest uosobieniem „tak” jako odpowiedzi Chrystusa na wolę swojego Ojca. To ucieleśnione „tak” zostaje przeniesione w strukturze metonimii ${ }^{10}$ na Syna Bożego. ${ }^{11}$

Skoro więc słowo 'āmēn/amēn ma charakter silnie potwierdzający, dlatego użyte jako tytuł Chrystusa wskazuje na wewnątrztrynitarny dialog między Ojcem i Synem i oznacza, że Jezus Chrystus jest ostateczną pozytywną odpowiedzią („mocnym tak”) na każde oczekiwanie Ojca, jest również urzeczywistnieniem wszelkich Jego zapowiedzi i wypełnieniem wszystkich Jego obietnic, a nadto - jest gwarancją wysłuchania próśb zanoszonych przez ludzi. Objaśnia to Paweł, gdy pisze: „Syn Boży, Chrystus Jezus (...) nie był „«tak» i «nie», lecz dokonało się w Nim «tak». Albowiem ile tylko jest obietnic Bożych, wszystkie są «tak» w Nim" (2Kor 1,19-20).

W Chrystusie wszystko jest „tak” dla Ojca, wszystko aprobuje Jego wolę i wszystko utożsamia się z nią. Dzięki Jego „tak” mogły się urzeczywistnić zapowiedzi proroków o przyjściu Zbawiciela i może się spełniać mesjańska obietnica o Emmanuelu - Bogu, który „zamieszkał wśród nas” (J 1,14).

Ponieważ terminu 'āmēn/amēn używa się też, by zapewnić o prawdziwości i powadze wypowiadanych słów, dlatego imię Chrystusa $A m \bar{e} n$ wskazuje też, że wszystko, co On mówi, jest prawdą; dlatego

9 Por. Fil o n A le ks a n d r y j k i, De Sacrificiis Abeli et Caini (91-92): „Rzeczywiście Bóg nie potrzebuje świadka, bo nie ma innego boga, który byłby $\mathrm{Mu}$ równy".

10 Metonimia (zamiennia) to figura retoryczna, w której nazwę jakiegoś przedmiotu lub zjawiska zastępuje się nazwą innego, pozostającego z nim w uchwytnej zależności.

${ }_{11}$ Por. L. C o 1 e m a n (red.), Nowy Testament dla moderatorów, Warszawa 2008, s. 595. 
można na Nim całkowicie polegać i ufać Jego obietnicom, ponieważ są prawdziwe ponad wszelką wątpliwość.

Drugi tytuł Chrystusa w Liście do Kościoła w Laodycei, „Świadek wierny i prawdomówny", jest de facto rozwinięciem imienia Amen. Skoro Chrystus jest Słowem Boga prawdziwego i Jego prawdomównym Wysłannikiem, wiernie odsłaniającym głębokości Boże, dlatego w pełni przysługuje Mu tytuł Amen. Nadto również w stosunku do Laodycejczyków Jezus jest Amen, ponieważ potwierdza w liście ich tragiczny stan duchowy.

\section{Inna propozycja interpretacji Ap 3,14}

W tradycyjnej interpretacji Ap 3,14 traktuje się tytuł Chrystusa Amēn jako grecką transliterację hebrajskiego słowa 'àmēn. Proponowana $\mathrm{w}$ niniejszym opracowaniu inna interpretacja imienia Chrystusa opiera się na odmiennym źródłosłowie terminu amēn. Zostanie on potraktowany jako dwuczłonowe słowo złożone, a dokładniej - jako zrost dwóch członów, „a” i „men”.

Pierwszym członem słowa amēn jest alpha privativum (,a” pozbawiające). Tak określa się gramatycznie po łacinie literę alpha użytą jako przedrostek w słowach greckich, by nadać im znaczenie przeciwne (przed słowami rozpoczynającymi się od samogłoski alpha privativum przybiera formę ,an”-). ${ }^{12}$ Alpha privativum wywodzi się protoindoeuropejskiej sylabicznej spółgłoski nosowej „n-”.

Przykłady kilku słów greckich z alpha privativum: nomos - anomos („,prawo” - „nieprawy”, np. w Mt 15,28), karpos - akarpos („owoc” - „bezowocny”, np. w Jud 12), taktos - ataktos (,regularny” - „nie trzymający się szyku”, np. w 1 Tes 5,14), halas - analos („,sól” - „będący bez soli”, np. w Mk 9,50).

Drugim członem słowa amēn jest nazwa własna Mēn - imię anatolijskiego bóstwa.

12 Po grecku alpha privativum określa się jako kata sterēsin. 


\section{Men - bóstwo Azji Mniejszej}

Men (Mèn, niekiedy Meis, łac. Mensis) był bóstwem hellenistyczno-rzymskim czczonym na tym obszarze Azji Mniejszej, który nazywa się Anatolią. Pierwotne pochodzenie Mena i jego powiązania z innymi kultami bliskowschodnimi są bardzo trudno uchwytne. Niektórzy orientaliści uważają, że jego korzenie mogą sięgać religii babilońskich w Mezopotamii w IV tysiącleciu przed Chr., a wzorcem Mena mogło być czczone tam bóstwo lunarne Sin. ${ }^{13}$ Inni badacze wiążą Mena z perskim bogiem księżyca $\mathrm{Mao}^{14}$ albo też z czczonym w Luwii bóstwem księżyca Arma. ${ }^{15}$ Pisarze starożytni powiązali kult Mena z Frygią.

Ekspansja kultu Mena z obszaru Frygii i Lidii nastąpiła w czasach hellenistycznych, poczynając od III w. przed Chr. i ogarnęła całą Azję Mniejszą oraz Grecję kontynentalną. Ponowna ekspansja kultu Mena nastąpiła w Cesarstwie Rzymskim w I w. po Chr. oraz w kolejnych stuleciach. Świadczyć o tym mogą monety z wyobrażeniem boga Mena znajdowane na terenach odległych od Frygii (np. w Palestynie czy Arabii). ${ }^{16}$

W ikonografii boga Mena dominuje symbolika lunarna. Bóstwo jest przedstawiane zazwyczaj jako brodaty mężczyzna z półksiężycem za plecami, w płaszczu i czapce frygijskiej. Wspiera się na długim berle albo włóczni, w drugiej ręce trzyma wielką szyszkę

13 Por. L. G u e r i n i, Men, w: (Zbior.) Enciclopedia dell'arte antica, classica ed orientale, t. 4, Roma 1961, s. 1001-1002.

14 Por. Men, w: Encyclopaedia Britannica, London 2003, t. 7 s. 1044.

15 Być może kult Mena był kontynuacją kultu lunarnego bóstwa Hetytów Army, którego później utożsamiano z Hermesem. Podobieństwo imion Arma i Hermes mogło wpłynąć na popularność boga Mena w tamtym regionie; por. M. P o p k o, Religions of Asia Minor, Warsaw 1995, s. 168.

16 Por. http://pl.wikipedia.org/wiki/Men_\%28b\%C3\%B3stwo\%29\#cite_note-3 (dostęp: 12 II 2015). 
sosnową, a nogą depcze czaszkę byka. Strabon opisuje go jako bóstwo nadzorujące miesiące. ${ }^{17}$

Wyobrażenia boga Mena dzielą się zasadniczo na dwie kategorie: jako postaci stojącej i rzadziej - jako jeźdźca na koniu lub baranie. Niekiedy Men powozi rydwanem zaprzężonym w byki; zdarza się też, że bykom towarzyszy lew.

Do naszych czasów nie zachował się żaden posąg Mena, choć wiemy, że takowe istniały (np. w Smyrnie). Dlatego ikonografia bóstwa pozostaje niejasna i zasadniczo opiera się na wizerunkach Mena zachowanych na monetach z okresu Cesarstwa Rzymskiego. Powtarzającym się atrybutem Mena jest, jak przystało na bóstwo lunarne, wyobrażenie półksiężyca.

Materialnych śladów kultu Mena zachowało się również niewiele. Do dziś przetrwały ruiny świątyni ku czci tego bóstwa w Antiochii Pizydyjskiej. ${ }^{18}$ Strabon wspomina, że do tego sanktuarium przynależały wielkie obszary ziemskie oraz niezliczone rzesze niewolników. ${ }^{19}$ Strabon wzmiankuje też dwa sanktuaria boga Mena w okolicy miast Laodycea i Karura na pograniczu Lidii i Karii, ${ }^{20}$ a nawet w okolicach Aten. ${ }^{21} \mathrm{O}$ kulcie boga Mena na wyspach Rodos, Delos i Tasos świadczą zachowane tam inskrypcje. ${ }^{22}$ „Kult potężnego w Azji boga Mena, którego symbolem był księżyc, identyfikowanego z czasem z Attysem, ograniczał się swym zasięgiem do wschodniej części

17 Por. S t r a b o, Geographia XII, s. 557, 577; P r o c 1 u s, In Platonis Timaeum commentaria IV, 251.

18 Ruiny świątyni boga Mena odkrył W. Ramsay w 1911 r. na wzgórzu Karakuyu w Antiochii Pizydyjskiej (dzisiaj Yalvaç w Turcji); por. Journal of Roman Studies 16/1926, s. 111; 17/1927, s. 112; M. H a r d i e, The Shrine of Mên Askaenos, Journal of Hellenic Studies 32/1912.

19 Por. M. P o p k o, Religions of Asia Minor, s. 192.

20 Por. S t r a b o, Geographia XII, s. 580.

${ }^{21}$ Por. tamże, s. 557. Kult Mena był popularny w III w. przed Chr. wśród niewolników w Attyce.

${ }^{22}$ Por. F. W a 1 t o n, Men (Mív), w: The Oxford Classical Dictionary, Oxford 1961, s. 556. 
PIOTR OSTAŃSKI

Imperium", ${ }^{23}$ ale sięgał daleko na wschód, co poświadcza założona w czasach perskich świątynia Mena w Kabejra (dziś Niksar) w Amerii. ${ }^{24}$

Również trudne do odtworzenia są formy kultu boga Mena. Imieniu bóstwa towarzyszyły przydomki Ouranios („,pan niebios”) i Katachtonios (,pan podziemi”), co wskazywało na zasięg jego władzy i oddziaływania. ${ }^{25}$ Innym przydomkiem Mena był Tyrannos („pan”, „sędzia”). ${ }^{26}$ Bóstwo określano też lokalnymi przydomkami, np. w Pamfilii był czczony jako Men Phosphoros, w Poncie - Men Pharnakos, a w Antiochii - Men Ascaenos. Czczono go jako wybawcę biednych, chorych oraz bezbronnych i wierzono, że jego moc dociera do wszystkich potrzebujących przez rogi półksiężyca umieszczone za plecami. Mena wzywano też jako strażnika nagrobków, umieszczając stosowne modlitwy i wizerunki na stelach nagrobnych. Nadto Strabon wspominał moc uzdrowicielską boga Mena i istnienie szkół lekarskich przy jego świątyniach. ${ }^{27}$

Men był również uważany za bóstwo wieszczące, dlatego przypuszcza się, że jego wyrocznie istniały m.in. w Attalei (Izauria) i w Anaburze (Pizydia). Natomiast potwierdzone są misteria małoazjatyckie związane $\mathrm{z}$ jego kultem. ${ }^{28}$ Zachowała się również wzmianka sugerująca, że cesarz rzymski Karakalla († 217) czcił Mena pod zlatynizowanym imieniem Lunus. $^{29}$

23 Zob. M. J a c z y n ow s k a, Religie świata rzymskiego, Warszawa 1987, s. 200.

24 Por. M. Popko, Religions of Asia Minor, s. 192.

25 Podobnie hetycki bóg Słońce był czczony jako Słońce Nieba i Słońce Ziemi; por. tamie, s. 192.

${ }^{26}$ Por. P. Wa r s ińs ki (red.), Mitologia Egiptu i starożytnego Wschodu. Kompendium, Warszawa 2004, s. 132.

27 Por. S t r a b o, Geographia XII, s. 580.

28 Por. A. Le sk y, Men, w: A. P a u ly, G. W is s ow a, W. K rol1, K. W it te, K. M it t e $1 \mathrm{~h}$ a u s, K. Z i e g 1 e r (red.), Pauly's Real-Encyclopädie des classischen Altertumswissenschaft, t. 16/1, Stuttgart 1931, kol. 697.

29 Por. http://penelope.uchicago.edu/Thayer/E/Roman/Texts/Historia_Augusta/ Caracalla*.html (dostęp: 12 II 2015), rozdz. 7. 
Z czasem kult boga Mena zaczął słabnąć na korzyść oficjalnych kultów imperialnych, w tym kultu władcy. Wydaje się, że niejasna geneza tego bóstwa oraz jego wielopostaciowość przyczyniły się do tego, iż jego kult był wchłaniany przez kulty silniejsze, np. przez misteryjny kult Kybele, a także Attysa, z którym zaczęto go, jak już wspomniano, utożsamiać. Men uległ wtopieniu w system synkretyzmu religijnego późniejszych okresów Imperium Romanum; ${ }^{30}$ utożsamiano go nie tylko z Attysem, ale też z trackim Sabaziosem i z Zeusem Dolichenosem. Pojawiał się też w misteryjnym kulcie obok Mitry. ${ }^{31}$

\section{Sens imienia Chrystusa ,a-Men”}

Z przytoczonych powyżej informacji wynika, że anatolijskie bóstwo Men było w starożytności najbardziej utożsamiane z Frygią i że we frygijskim mieście Laodycea, a także w innym mieście na pograniczu frygijsko-pizydyjskim, w Antiochii Pizydyjskiej, wzniesiono sanktuaria ku jego czci. To potwierdza, że na tamtych terenach jego kult był szeroko rozwinięty.

Wzmianka o bogu Men w Liście do Kościoła w Laodycei ma swoje Sitz im Leben w uwarunkowaniach kultycznych tego frygijskiego miasta oraz w sytuacji tamtejszego Kościoła. Jest znamienne, że spośród siedmiu listów w Apokalipsie tylko ten do Kościoła w Laodycei nie zawiera żadnej pochwały, a wprost przeciwnie - same nagany. Tamtejsza wspólnota chrześcijańska zobojętniała i nie była ani gorąca, ani zimna. Widocznie Chrystus przestał być dla nich Kyriosem. A mimo tego Jezus ich nie odrzucił, ale zapewnił, że „stoi u drzwi i kołacze" (Ap 3,20), wzywając Kościół do nawrócenia.

W przytoczonym tu źródle jest też zawarte przeświadczenie, że jeśli mężczyzna uważa bóstwo lunarne za kobietę, będzie w życiu zawsze uległy żonie, a jeżeli za mężczyznę - będzie nad żoną dominował.

30 Por. F. Wa 1 t o n, Men (Mív), s. 556.

31 Por. M. V e r m a s e r e n, Enciclopedia dell'arte antica, classica ed orientale, t. 6, Roma 1963, s. 118. 
Zadowolonym z siebie i obojętnym chrześcijanom z Laodycei proponuje symboliczne zakupy, które pomogą im dokonać metanoi.

Słowa Chrystusa w Liście do Laodycei są niezwykle surowe. $\mathrm{W}$ ten klimat doskonale wpisuje się samookreślenie Chrystusa Amēn. Pan nazywa siebie pieczęcią w Kościele i dla Kościoła, jak to wynika z tradycyjnej interpretacji imienia ho Amēn.

Ale nie tylko. Chrystus nazywa siebie $A$-Men (,Nie Men”). Tym określeniem uzmysławia chrześcijanom w Laodycei, że nie jest Menem, choć tak próbują na Niego patrzeć. Nie jest częścią pogańskiego panteonu, nie jest bożkiem bezsilnym wobec świata i jego problemów, nie jest ludzkim wymysłem. W przeciwieństwie do bożka Mena i jemu podobnych jest prawdziwym Bogiem, jest „Tym, Który jest" (Wj 3,14).

A kolejne dwa określenia Chrystusa z Ap 3,14 są potwierdzeniem i rozwinięciem Jego tytułu „Nie Men”. Chrystus ,,jest Świadkiem [martys] wiernym i prawdomównym". Grecki termin martys zaczęto bardzo szybko stosować w odniesieniu do tych świadków, którzy własną krwią przypieczętowali swoje słowa. Jezus przypomina Kościołowi w Laodycei, że na każdym swoim słowie przystawił pieczęć z własnej krwi i swoim męczeństwem potwierdził własną prawdomówność i wiarygodność. Nie jest Menem, nic nie znaczącym bożkiem, ale Bogiem, który troszczy się o cały świat, gdyż jest „Początkiem stworzenia Bożego".

Zaproponowana $\mathrm{w}$ niniejszym szkicu interpretacja imienia Chrystusa „Amen” rzuca nowe światło na chrystologię Apokalipsy i ją wzbogaca. Jezus, zestawiając swoją osobę z bożkiem pogańskim Menem, popularnym wśród tych, do których skierował słowo w liście, odsłania przed nimi prawdę o swoim bóstwie, o swej absolutnej wyższości nad idolami pogańskimi i o wynikających z tego faktu konsekwencjach.

Problematyka absolutnej dominacji Boga nad bałwanami pogańskimi powracała często na kartach Starego Testamentu, a zwłaszcza 
w pouczeniach proroków (np. w Iz 2,20; 43,10-12; 44,9-20; 45,20-22; 46,5-9; Jr 5,7; 7,16-20; Mi 5,12; Ha 2,18-20; Oz 8,4-6). W pismach Nowego Testamentu bożki pogańskie przybierają często postać rzeczywistości doczesnych, które odciągają ludzi od prawdziwego Boga, np. pieniędzy (Mt 6,24), wina (Tt 2,3), żądzy panowania nad innymi (Kol 3,5; Ef 5,5), władzy politycznej (Ap 13,8), przyjemności, zazdrości, nienawiści (Rz 6,19; Tt 3,3), grzechu (Rz 6,6) czy zaledwie materialnego przestrzegania Prawa (Ga 4,8-9). Autorzy natchnieni tylko okazjonalnie poruszają problematykę kultu bożków pogańskich (np. w Dz 15,29; 17,16.29; 1Kor 12,2; Ga 4,8), nigdy zaś nie zestawiają z nimi Chrystusa. Wyjątkiem może być tekst Ap 3,14 z samookreśleniem Chrystusa „Nie Men”. Jezus Chrystus uczy, że nie jest jednym z wielu bogów, ale ich kompletnym przeciwieństwem, czyli Bogiem prawdziwym, „który JEST”. 